Land Change Detection and Effective Factors on Forest Land Use Changes: Application of Land Change Modeler and Multiple Linear Regression

\author{
1*JAHANIFAR, K; ${ }^{2}$ AMIRNEJAD, H; ${ }^{2}$ MOJAVERIAN, M; ${ }^{3}$ AZADI, H \\ ${ }^{I}$ Department of Agricultural Economics, Sari Agricultural Sciences and Natural Resources University, Sari, Iran Corresponding Author E- \\ mail: mashaykhan@yahoo.com \\ ${ }^{2}$ Department of Agricultural Economics, Faculty of Agricultural Engineering, Sari Agricultural Sciences and Natural Resources University, \\ Sari, Iran \\ ${ }^{3}$ Department of Geography, Ghent University, Ghent, Belgium \\ *Corresponding Author E-mail: mashaykhan@yahoo.com
}

\begin{abstract}
Reducing forest covered areas and changing it to pasture, agricultural, urban and rural areas is performed every year and this causes great damages in natural resources in a wide range. In order to identify the effective factors on reducing the forest cover area, multiple regression was used from 1995 to 2015 in Mazandaran forests. A Multiple regressions can link the decline in forest cover (dependent variable) and its effective factors (independent variable) are well explained. In this study, Landsat TM data of 1995 and Landsat ETM+ data of 2015 were analyzed and classified in order to investigate the changes in the forest area. The images were classified in two classes of forest and non-forest areas and also forest map with spatial variables of physiography and human were analyzed by regression equation. Detection satellite images showed that during the studied period there was found a reduction of forest areas up to approximately 257331 ha. The results of regression analysis indicated that the linear combination of income per capita, rain and temperature with determined coefficient 0.4 as independent variables were capable of estimating the reduction of forest area. The results of this study can be used as an efficient tool to manage and improve forests regarding physiographical and human characteristics.
\end{abstract}

\title{
DOI: https://dx.doi.org/10.4314/jasem.v22i8.20
}

Copyright: Copyright (C) 2018 Jahanifar et al. This is an open access article distributed under the Creative Commons Attribution License (CCL), which permits unrestricted use, distribution, and reproduction in any medium, provided the original work is properly cited.

Dates: Received: 29 June 2018; Revised: 27 July: 2018; Accepted: 26 August 2018

Keywords: Land change Modeler, Multiple linear regression, remote sensing, Mazandaran forests

Land cover refers to the habitat or present vegetation type, such as forest and agriculture area. Land-use and land-cover change (LUCC) also known as land change is a term for the human modification of Earth's terrestrial surface. It is widely accepted that LULC has an important effect on both the functioning of the Earth's systems as a whole (Lambin et al., 2001) and the majority of ecosystems (Hansen et al., 2001; Millennium, 2005; Fischlin et al., 2007). This change is based on the purposes of need, which is not necessarily only making the change in land cover but also change in intensity and management (Verburg et al., 2000). Historically, the most important change in land use which is done by people has been destroying forests and converting them into agricultural lands and habitats (Lausch and Herzog, 2002). The values related to the goods and services that forest ecosystems present are evident. Forests present the vast domain of ecosystem services, from balancing carbon cycle up to maintaining and wetting water cycle and maintaining genetic reservoirs and many other known and unknown materials (Slee, 2007). The amount of forest cover is changed during time, whether by natural factors or by the man himself and the most important factors of decrease in the level of these regions include: changing forest usage to agricultural and residential lands because of high ratio of population growth, using woods as the resource of fuel and energy by local people specially in bereaved sectors, roads, communication and power (electricity, gas, etc.), presence and cattle in forest arenas, firing and gradual destruction of forest and decrease in its vastness due to the pollution of environment and warmness of earth (Ding Change, 1990).Therefore, it is determined that human activity is the most important factor of destroying forests. North forests of Iran and Alborz mountains have special importance with respect to scope and environmental issues, maintained water and soil resources that during past decades have lost their production capability because of the impact of social and economic factors, lack of comprehensive management of natural resources. It lost its production capability so that this procedure has compromised the future of the forests of the region (Mahdavi et al., 2012). Thus, for stable management and maintaining of these resources, knowing the extent and place of

*Corresponding Author E-mail: mashaykhan@yahoo.com 
deforestation, the speed and surface, the causes and reasons of reducing forest land cover are necessary. Remote sensing by satellite image provides an important resource of data related to usage and land cover (Rafieyan et al., 2007). The data is used for detecting, quantifying and mapping local pattern of changes of land use (AbdEl-Kawy et al., 2011). Not only the capabilities of analysis of geographical information can provide analysis of type, condition and extent in destruction, but also detecting forest land cover changes by remote sensing data in GIS medium can present suitable recognition of how to change forest land cover and recommend suitable strategies in its management (Bakr et al., 2010). One of the tools used by planners to control the trend of forest cover changes is regression relations. According to the fact that environmental science is dealt with different phenomena, so in ecological issues, multiple regression has much importance (Bihamta et al.., 2011). The linear multiple regression is a technique to analyze the relation between some variables. In linear multiple regression, we assume that there is a linear relation between dependent and independent variables (Salman Mahini and Kamyab, 2012). Using remote sensing data and linear multiple regression equation in GIS medium provide suitable recognition of how to change forest land cover and determine the effective factors on it. The general objective of the present paper is to estimate the land use changes over time. For this study, analysis is performed by a remote sensing based Land Change Modeler (LCM) method.

\section{MATERIALS AND METHODS}

Mazandaran forest (MF) is located in the north-east region of Iran (See Fig. 1). The case study forests, extend from Babol in the middle of Mazandaran province to Behshar in the east and cover the northern slope of the Alborz Mountain with $350 \mathrm{~km}$ length and 20-70 km width. The annual growth of the forests differs with regard to tree species, site, age and density and ranges from 2 to $8 \mathrm{~m}^{3} / \mathrm{ha}$ in a year (Abbasi and Mohammadzadeh, 2010). The MF extends from sea level to 2,800 $\mathrm{m}$ and mainly consists of mixed forests of Beech, Maple, Oak, Hornbeam, and Alder. The climate of the region is wet Mediterranean. The average annual temperature of the plateau region is $16-18^{\circ} \mathrm{C}$, with high relative humidity especially in the summer. Appropriate climatic conditions of the region have made it habitable to many hardwood species. More than 83 tree and 51 shrub species are recognized in the MF.The forest area was estimated to be $1,295,237$ ha in the past; today, however, it decreased to 794,014 ha $[15 \%$ of the total forest area (12.4 million ha)] or $1.1 \%$ of the total area of Iran. In Iran, this index is 0.2 ha per person, while globally, it is 0.8 ha. This amount indicates poverty and shortage of our country. On the basis of FAO's statistics in 2011, forest areas of 149 and 45 countries were lower and larger than Iran, respectively. Unfortunately, despite the low per capita situation, about one-third of the forests (about 7 million ha) has been destroyed in the recent four decades, i.e., 200,000 ha annual deforestation. Of 200,000 ha of our forests, 45,000 ha belongs to MF.

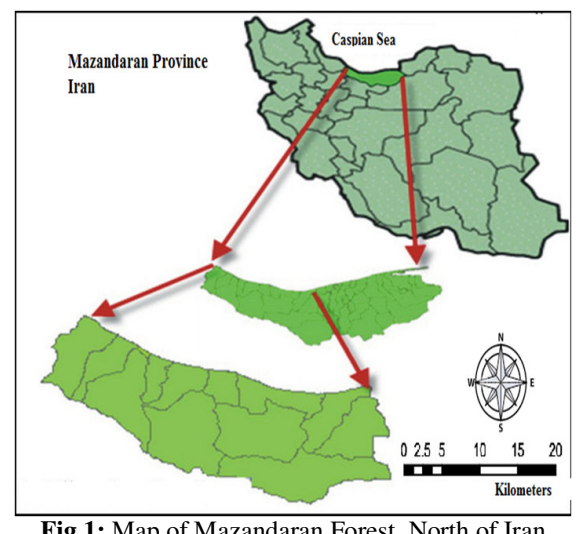

Used data: In order to attain the qualified changes occurred in the forest region, measuring Landsat satellite images TM of 1988 and ETM (Enhanced Thematic Mapper Plus) of 2007 were used which both are related to column 167 and row 39. Similarly, topographic maps with a scale of 1: 50,000 related to 1925 prepared by the Geographic Organization of the Armed Forces for the creation of a digital elevation model (DEM), the selection of ground control points for geometric correction and the assessment of the accuracy of the satellite image classification as well as the provision of road data And residential areas.

Classifying satellite images: In this research each image related to both temporal domains was classified through the supervised classification. The first step in conducting a supervised classification is the definition of areas that are used as educational examples for each class (Lambin et al., 1999). For this stage, with the visual interpretation of the false color combination, using the topographic maps, the training samples for each class were defined. After selecting suitable educational samples, the size of resolution and contrast between classes were studied. Usually contrast between two classes implies that those two classes have the most statistical distance and the highest possibility for the accurate classification. To measure the extent of resolution of classes towards each other, divergence criteria were computed. It should be considered that the method of maximum classification of contingency is the most common (Darvish sefat and Pire Bavaghar, 2012) and the most accurate method 
among the existing classifying methods (Zobeiry and Majd 2011). According to this issue, classifying was done with the maximum contingency.

Preparing the map of earth reality: In this study, 120 samples were selected in forest and non-forest areas randomly on the images obtained from classification in areas that have not been changed in the both periods. The place of samples was localized by colored combination images related to both periods as well as the images captured by Google Earth and was codified. In order to evaluate the map of earth reality, a sample with the results of classification was converted to raster format. The results of the classification were evaluated using the maximum probability method with the created ground map, and the overall accuracy and kappa coefficient were obtained.

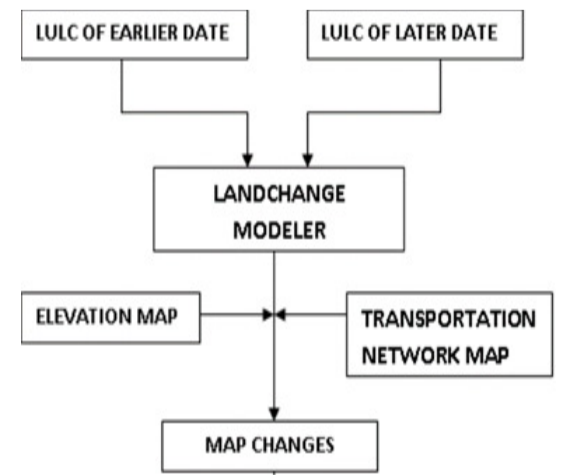

Fig 2: Flow Chart Showing the Methodology (Step 1)

Linear multiple regression: In linear multiple regression, we assume that there is a linear relation between dependent variables and independent variables. By having dependent variable, linear multiple regression equation will be as equation 1 .

$Y=a+\beta_{1} x_{1}+\beta_{2} x_{2}+\cdots+\beta_{n} x_{n}$

In which $\mathrm{Y}$ is a dependent variable, $\mathrm{x}_{1}, \mathrm{x}_{2} \ldots \mathrm{x}_{\mathrm{n}}$ are dependent variables. $b_{1}, b_{2} \ldots b_{n}$ are coefficient of dependent variables. The constant coefficient a represents the value of $\mathrm{Y}$ in the time being Zero of all the dependent variables. Moreover, the coefficients of parameters state the change in $\mathrm{Y}$ for one unit increase in the related dependent variable (Estman, 2012). In this study, the map of the destruction of forest cover as a dependent variable and digital elevation data from the sea level, distance from the road, distance from residential areas and the direction of the slope as effective parameters in the process of decreasing forest cover as independent variables in establishing a linear multiple regression was applied. In order to evaluate linear multiple regression model, determination coefficient $\left(\mathrm{R}^{2}\right)$ and root mean square error (RMSE) were used. Determination coefficient means that how much the changes of dependent variable are related to independent variable. The root mean square error is the difference between the expected value by the model or statistical estimator and real value that in general is obtained by equation 2 :

$\mathrm{RMSE}=\sqrt{\frac{\sum_{i=1}^{n}\left(y_{o b s}-y_{\text {model }}\right)^{2}}{n}}$

In the above relation $\mathrm{y}_{\mathrm{obs}}$ and $\mathrm{y}_{\text {model }}$ are observed value and estimated value by model respectively and $\mathrm{n}$ is the number of data (Chang et al., 2005).

\section{RESULTS AND DISCUSSION}

After determining the degree of separation in the classes, the classification of the relevant survey images is based on the results which obtained from the classification of forests and non-forests using the other equation indicating a proper separation of the land cover classes. (Table 1). The results of evaluating the accuracy of the classified images have been given in Table 2. According to the high values of Kapa coefficient (0.87), we can use these images (Fig. 3 and 4) to study the decrease in forest land cover of Mazandaran Province.

\begin{tabular}{lll}
\multicolumn{3}{l}{ Table 1: The degree of separation of land cover classes using the divergence criterio } \\
\hline Land use classes & Separability value & Separability statue \\
\hline Forest & 1.99843 & Good \\
Others & 1.98742 & Good \\
Average Separability of all classes & 1.99439 & Good
\end{tabular}

\begin{tabular}{llll}
\multicolumn{4}{c}{ Table 2: } \\
The accuracy assessment of the satellite images classification \\
\hline 1995 & 2015 & \\
\hline General accuracy & Kapa coefficient & General accuracy & Kapa coefficient \\
$88 \%$ & 0.88 & $87 \%$ & 0.85 \\
\hline
\end{tabular}

The results of classifying showed that of whole surface of the region, about 268901 hectares were covered by forest and 239113 hectares were covered by non-forest lands, in 1995; while the surface area of forest have 
been 11570 hectares in 2015 (Table 3). The result of comparison between two maps related to the beginning and end of temporal period shows that 257331 hectares of forest regions have been decreased. It should be noted that according to the information obtained from the Natural Resources and Watershed Management Office of Mazandaran province during the studied period, no afforestation has taken place in the region. The value of gains and losses and net changes in forest and non-forest land use have been shown in Fig. 5 and 6.

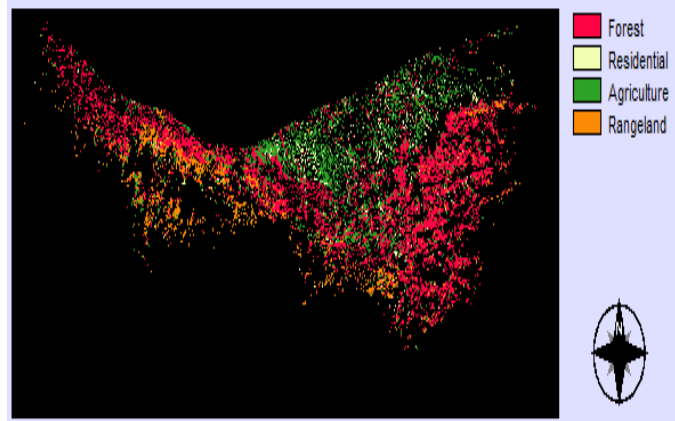

Fig 3: Land use map of study area for 1995

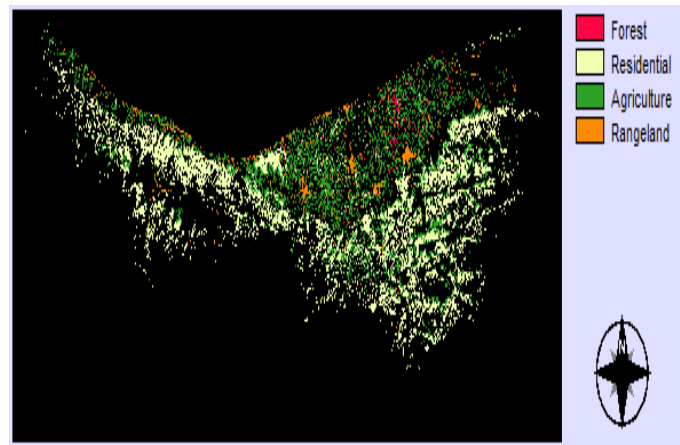

Fig 4: Land use map of study area for 2015

Table 3: Rates of change in forest cover area in 1995-2015

\begin{tabular}{llll}
\hline $\begin{array}{l}\text { Land use } \\
\text { classes }\end{array}$ & $\begin{array}{l}\text { Area of } \\
1995(\mathrm{HA})\end{array}$ & $\begin{array}{l}\text { Area of } \\
2015(\mathrm{HA})\end{array}$ & $\begin{array}{l}\text { Area of } \\
\text { Changes }(\mathrm{HA})\end{array}$ \\
\hline Forest & 268901 & 11570 & -257331 \\
Others & 239113 & 496444 & 257331 \\
Total & 508014 & 508014 & - \\
\hline
\end{tabular}

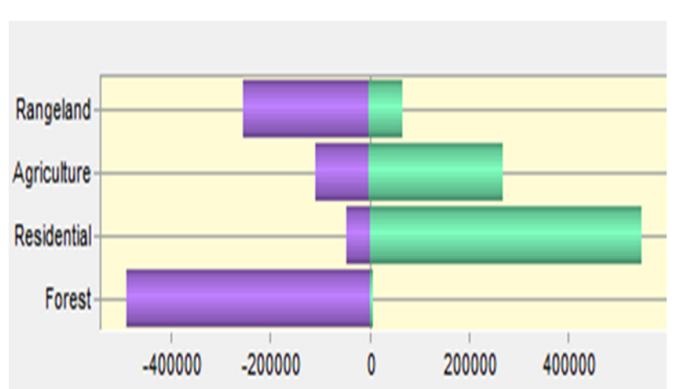

Fig 5: Gain and lose of land uses from 1995-2015

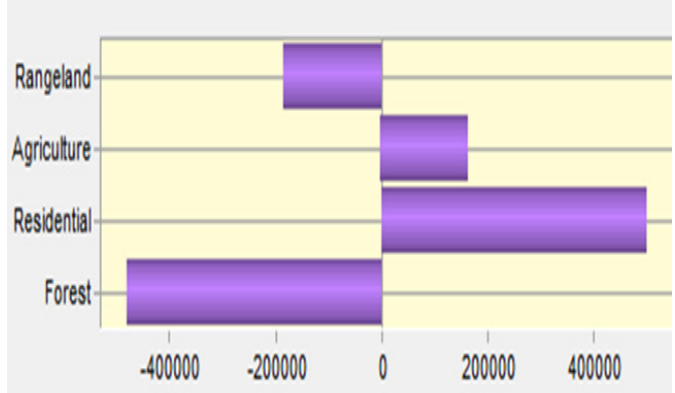

Fig 6: Net change of land uses from 1995-2015

After determining the location and extent of forest cover reduction areas, multiple linear regression was used to determine the relationship between factors affecting forest cover reduction. Digital elevation data, distance from residential areas, distance from road and slope direction as independent variables were constructed in GIS. Then, the linear regression relationship between forest cover reduction as a dependent variable with the mentioned parameters was established, which is shown in the table (4). Using the coefficient of determination, it is determined how much variable variation is dependent on the independent variable. (Bihamta and Zare, 2011). According to the value of determination coefficient which equals 0.4 , we can say that $38.89 \%$ of decreases in forest land cover in hectare have been made by independent variables and the value of RMSE shows that the contingency of model error is 0.652 hectare. According to the fact that the value of computed $F$ (5.92) is larger than $\mathrm{F}$ of the table with freedom degrees of 1 and 37 in the significant level of 5\% (2.62) (Table 5), we can claim that there is a significant linear relation between dependent and independent variables in the possibility level of $95 \%$. The values of $t-$ statistics from T-student table are extracted for freedom degree 37 which is used to test the significance of dependent variables. Given that $t$ is extracted from the table for level of significance $99 \%$ and $8 \%$ with freedom degree of 37 are 2.62 and 1.2 (Table 6). It can be concluded that since the t-value of variables elevation from sea level, distance from road and direction of slope are higher than 2.62, the impact of these variables on change in forest cover is very significant, while the variable temperature is less significant.

In order to determine the significance of independent variable, sensitization of the model was measured. Measuring the sensitization of the linear multiple regression model was done so that after performing the model with complete data series, the model is performed again for the number of independent variable, with the difference that this time in each stage of performing the model, one of the independent 
variables is omitted and the model is performed by the residual independent variables (Salman-Mahini and Turner, 2003). This research was conducted with the objective of determining the factors effective on decreasing forest land cover in the forest region of Mazandaran province. The impact of four factors income per capita, population, rain and temperature were studied on the extent of decrease in forest land cover. In order to determine the relation of mentioned factors with decrease of forest land cover, linear multiple regression statistical method was used.

Table 4: Results of Multiple Linear Regression Model

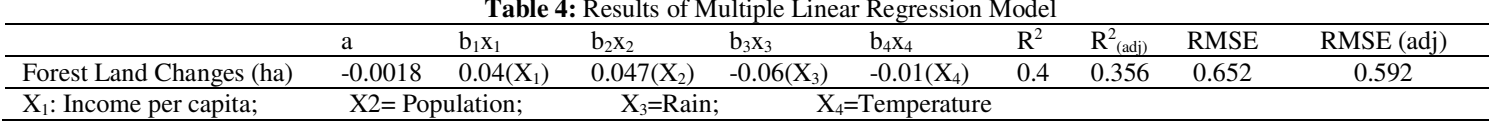

Table 5: Variance analysis of Multiple Linear Regression

\begin{tabular}{llllll}
\hline & d.f. & $\begin{array}{l}\text { Sum of } \\
\text { squares }\end{array}$ & $\begin{array}{l}\text { Mean of } \\
\text { squares }\end{array}$ & F & sig \\
\hline Regression & 4 & 8012.6 & 2004.16 & 5.91 & $5 \%$ \\
Residual & 37 & 12590.7 & 344.28 & & \\
Total & 41 & 20603.3 & & & \\
\hline
\end{tabular}

Table 6: Comparison of the significance levels of independent variables

\begin{tabular}{llll}
\hline Variables & $\mathrm{t}$ from T-Student & $\mathrm{t}$ from Multiple Linear Regression & Sig. level \\
\hline Income per capita & 2.62 & 18.45 & $99 \%$ \\
Population & 2.62 & 6.88 & $99 \%$ \\
Temperature & 1.2 & 1.39 & $80 \%$ \\
Rain & 2.63 & 5.32 & $99 \%$ \\
\hline
\end{tabular}

According to the outputs of regression equation and the value of its $F$, we can claim that there is a significant relation between dependent and independent variables; so that t-value obtained from linear multiple regression equation shows that these four factors have less significant relation with forest land cover. The value of determination coefficient shows that $38.89 \%$ of forest land cover decrease has been conducted in forest region of Mazandaran province by independent variables. According to the fact, the income per capita have the highest coefficient in linear multiple regression equation, which is considered as most important factor in decreasing forest land cover, so the results show that by an increase in income per capita more destruction has occurred and this issue is returned to develop rural, urban and tribes population in income per capita (Gole et al., 2006). Therefore, it can have a significant effect on absorbing the factors of destruction so that residential regions, lands under cultivation, pastures suitable to feed cattle and suitable entertaining regions are placed in middle heights of the studying region.

Currently, the main factor in reducing forest cover in the region is human activity. Residents of residential districts and nomadic communities in the area are busy removing and cutting off the trees to cover their fuel consumption and the expansion of their agricultural lands. The excessive slaughter of livestock also destroyed the forest cover in the area, which owners of livestock, regardless of the issue of vegetation degradation and the consequent consequences of it in the future, set up their animals for some time in a region and after the assignment And the end of the vegetation of the region goes to another point and destroys it. Increased development in the region and urbanization tend to increase the use of forests from residential to residential, as well as meet the needs for converting forest lands into agriculture, which has led to a large decline in forest lands. In order to protect these forests, the use of extension programs for indigenous people and stakeholders is essential. Obviously, it should not be forgotten that the outcome of policies in the natural arenas and forests depends on the participation of the people, because these people are the target audience of the programs, and they must play their destructive role with the positive role that is needed in preserving forests to carry it out. Nowadays, there is no doubt that, in line with the goals of humanoriented popular development programs, education has a high rank and special status through increasing the participation rate of people. Therefore, to transfer educational programs and policies to prevent forest degradation, the establishment of a comprehensive forest management training program for the natives should focus on a large part of the current problems of forests.

\section{REFERENCES}

Abbasi, A; Mohammadzadeh, S (2010). Investigation of world experiences for local participation on forest resources management and utilization of successful experiences in Iran. North Forests Management and Sustainable Development, $774 \mathrm{p}$. 
AbdEl-Kawy, OR; Rod, JK; Ismail, HA; Suliman, AS (2011). Land use and land cover change detection in the western Nile delta of Egypt using remote sensing data, Applied Geography. 31(2): 483-494.

Amini, MR; Shataee-Joybari, Sh; Moaieri, MH; Ghazanfari, H (2009). Deforestation modeling and investigation on related physiographic and human factors using satellite images and GIS. Iranian Journal of Forest and Poplar Research. 16(3): 431-443.

Agheli, KL (2003). Green GNP calculation and sustainable degree of national income in Iran. $[\mathrm{PhD}$ thesis] Humanities faculty, Tarbiat Modarres University, Tehran, 260 p.

Agricultural Organization of Ilam province (2007). Detailed studies of watershed Sari. 125p.

Bakr, N; Weindorf, DC; Bahnassy, MH; Marei, SM; El-Badawi, MM (2010). Monitoring land cover changes in a newly reclaimed area of Egypt using multi temporal Landsat data. Applied Geography. 30(4): 592-605.

Bagheri, R; Shataee-Joybari, Sh (2010). Modeling forest areas decreases, using logistic regression (case study: Chehl-Chay catchment, Golestan province). Iranian Journal of Forest. 2(3): 243252.

Bihamta, M; Zare-Chahouki, M (2011). Principles of statistics for the natural resources science. University of Tehran Press. 300p.

Chang, FJ; Chang, LC; Chiang, YM (2005). Reply to comment on comparison of static-feed forward and dynamic feedback neural networks for rainfall-runoff modeling. Journal of Hydrology. 314(14): 297-311.

Darvishsefat, AA; PirBavaghar, M (2012). Applied GIS. Iranian Student Book Agency (ISBA).Tehran, Iran. 236p.

Dingcheng, XU (1990). Detection of forest change using multi spectral scanner data. http//www.GISdevelopment.net/AARS/Arcs 199 $0 /$ poster session.

Estman, JR (2012). IDRISI Selva Tutorial. Clark Labs, Clark University, Worcester, Ma. 354p.

Fischlin, A; Midgley, GF; Price, JT; Leemans, R; Gopal, B; Turley, C; Rounsevell, MDA; Dube,
OP; Tarazona, J; Velichko, AA (2007). Ecosystems, Their Properties, Goods and Services [in:], M.L. Parry, O.F. Canziani, J.P. Palutikof, P.J. Vander Linden, and C.E. Hanson (eds.), Climate Change 2007 Impacts, Adaptation and Vulnerability, Cambridge: Cambridge University Press, 5(2): 211-272.

Jafarzadeh, AA; Arekhi, S (2012). Analyze and predict processes of deforestation using logistic regression and GIS. Elixir. Agriculture. 44(5): 7104-7111.

Gul, AM; Orucu, K; Oznur, K (2006). An approach for recreation suitability analysis to recreation planning in Golchuk Natural Park. Journal of Environmental Management. 37(5): 606-625.

Hansen, AJ; Neilson, RP; Dale, VH; Flather, CH; Iverson, LR; Currie, DJ; Shafer, S; Cook, R; Bartlein, PJ (2001). Global Change in Forests: Responses of Species, Communities and Biomes, Bioscience, 51(7): 765-779.

Helming, K (2008). Sustainability impact assessment of land use changes. Springer. Berlin, Heidelberg, New York. 507p.

Hosseinzadeh, MM; Derafshiand, K; Mirbagheri, B (2013). Modeling forest extent change and its influencing factors, using logistic regression model in GIS environment, Iranian Journal of Forest and Poplar Research. 21(1): 86-98.

Lambin, EF; Baulies, X; Bockstael, N; Fischer, G; Krug, T; Leemans, R; Moran, EF; Rindfuss, RR; Sato, Y; Skole, D; Turner, BL; Vogel, C (1999). Land-use and land-cover change (LUCC): Implementation strategy. IGBP Report No. 48, IHDP Report No. 10, Stockholm: IGBP.

Lausch, A; Herzog, F (2002). Applicability of landscape metrics for the monitoring of landscape change: Issues of scale, resolution and interpretability. Ecological Indicator. 1(1):3-15.

Mahdavi, A; Fallah-Shamsi, SR (2012). Mapping forest cover change, using aerial photography and IRS-LISSIII imagery. Journal of Wood \& Forest Science and Technology. 19(1): 77-92.

Mahapatra, K; Kant, S (2005). Tropical deforestation: A multinomial logistic model and some countryspecific policy prescriptions. Forest Policy and Economics. 7(2): 1-24. 
Mas, JF; Puig, H; Palacio, JL; Sosa-Lopel, A (2004). Modeling deforestation using GIS and artificial neural networks. Environmental Modeling \& Software. 19(5): 461-471.

Matthew, L; Robert, J; Smith, RJ; Nigel, LW (2004). Mapping and predicting deforestation patterns in the lowlands of Sumatra. Biodiversity and Conservation. 13(2): 23-37.

Millennium Ecosystem Assessment (2005). Ecosystems and Human Well-Beings: Biodiversity Synthesis, Washington, DC: World Resources Institute.

Miranda-Argon, L; Trevino-Garza, J; Jimenez-Perez, $\mathrm{J}$; Aguirre-Colderon, OA; Gonzalez-Tagle, MA (2012). Modelling susceptibility to deforestation of remaining ecosystems in North central Mexico with logistic regression, Journal of forestry Research. 23(3):345-354.

Miriam, SW; Taylor, VS (2010). Modeling social and land-use/land-cover change data to assess drivers of smallholder deforestation in Belize. Applied Geography. 30p.

Mohammadian, SM (2011). The role of public participation in natural resources (in Persian). National Proceedings of North Forests Management and Sustainable Development, Ranges and Forests Organization. Tehran, 22(5): 769-774.

Rafieyan, A; Darvish-Sefat, AA; Namyranian, M (2007). Determine changes in forest area north of the country from 1993 to 2003 using Landsat imagery ETM+. Journal of Science and Technology of Agriculture and Natural Resource. 10(3):277-286.

Salman-Mahini, A; Turner, BJ (2003). Modeling past change in vegetation through remote sensing and GIS: a comparison of neural networks and logistic regression methods. Proceeding of Geo computation Conference, Southampton, UK. 24p.
Salman-Mahini, A; Kamyab, H (2012). Applied Remote Sensing and GIS with Idrisi. $2^{\text {nd }}$ Edition. Publication of Mehrmahdis. Tehran, Iran. 596p.

Slee, B (2007). Landscape goods and services related to forestry land use. Multifunctional land use meeting future demands for landscape goods and services. Springer. Berlin Heidelberg. New York. $421 \mathrm{p}$.

Verburg, PH; Chen, Y; Soepboer, W; Veldkamp, A (2000). GIS-based modeling of human environment interactions for natural resource management. Applications in Asia [in:]. Proceeding 4th International Conference on Integrating GIS Environmental Modeling: Problems, Prospects and Research Needs, Banff, Alberta, Canada, Sept. 2 - 8, 2000, 1-18.

William, N (2000). Agricultural and Small Watershed Hydrology: Watershed Characteristic. Available at

http://www.egr.msu.edu/ northco2/WshedChar.h $\underline{\mathrm{tml}}$.

Wu, Q; Li, H; Wang, R; Paulussen, J; He, Y; Wang, M; Wang, B; Wang, Z (2006). Monitoring and predicting land use change in Beijing using remote sensing and GIS. Landscape and Urban Planning. 78 (4): 322-333.

Zare-Garizi, A; Sheikh, V; Sadoddin, A; SalmanMahini, A (2012). Application of logistic regression modeling of spatial pattern of vegetation change. Journal of Geographic Space. 12(37): 273-285.

Zobeiry, M; Majd, R (2011). An introduction to remote sensing technology and its Application in natural resource. 9th Edition, University of Tehran Press. 316p. 